\title{
Effect of easy calving beef sires on the birth weight and growth of dairy beef cattle
}

\author{
V.T. BURGGRAAF ${ }^{1}$ and D.B. LINEHAM ${ }^{2}$ \\ ${ }^{1}$ AgResearch, Ruakura Research Centre, PB 3123, Hamilton, 3240, New Zealand \\ ${ }^{2}$ Rezare Systems Limited, PO Box 9466, Hamilton 3240, New Zealand \\ vicki.burggraaf@agresearch.co.nz
}

\begin{abstract}
The impact of using high genetic merit beef bulls in a dairy beef supply chain was compared to using unrecorded beef bulls. Dairy cows were inseminated with Ezicalve Hereford semen (high genetic merit for calving ease and growth), followed by natural mating with Ezicalve and unrecorded Hereford bulls. The resulting 186 progeny were monitored from birth to 2 years old. Ezicalve sired calves required no calving assistance and averaged $4 \mathrm{~kg}$ lighter at birth than those from unrecorded sires $(\mathrm{P}<0.01)$, but took no longer to reach $100 \mathrm{~kg}$ liveweight. Liveweight gain during finishing was similar across sire types, but calves sired by artificial breeding were born an average of 5 weeks earlier than naturally sired calves and hence, averaged 20 to $35 \mathrm{~kg}$ heavier at any given date $(\mathrm{P}<0.001)$. There were also differences amongst Ezicalve sires in the liveweight gain of their progeny during finishing, generally reflecting their breeding values.
\end{abstract}

Keywords: birth weight, calving ease, dairy beef, liveweight gain

\section{Key messages}

- Dairy beef calves sired by Ezicalve Hereford bulls were lighter at birth than those from unrecorded Hereford sires and required no calving assistance.

- Dairy beef cattle sired by Ezicalve Hereford bulls had similar growth rates during rearing and finishing as calves sired by unrecorded Hereford bulls.

- Ezicalve Hereford sires used for artificial insemination differed in genetic merit and this was reflected in their progenies growth rates during finishing on hill country.

\section{Introduction}

With the national beef breeding cow herd continuing to decline (Beef + Lamb New Zealand 2014), New Zealand is becoming increasingly reliant on beef breed sired calves from dairy farms as a source of finishing cattle for beef production. These calves are mostly derived from natural mating and are often sired by bulls of unknown genetic merit. This results in many cattle entering the beef industry with a poor or unknown potential for growth. These cattle are also born late in the calving season, reducing their potential for being finished before their second winter.

Selecting appropriate beef bulls for use on dairy farms has the potential to add value to both the dairy and beef industries. Use of such bulls through both artificial breeding $(\mathrm{AB})$ and natural mating would provide a supply of calves for the beef industry throughout the calving season. However, to maximise the value of these calves to the beef industry, their growth potential should not be compromised.

Beef sires are available for both $\mathrm{AB}$ and natural mating with high Estimated Breeding Values (EBV's) for a combination of low birthweight, high calving ease and high growth rate. The Beef + Lamb New Zealand Dairy Beef Integration Programme was initiated to demonstrate the use of such beef sires on dairy farms and assess the impacts throughout the dairy beef supply chain, from mating to finishing. This paper reports the growth from birth to 2 years of age of dairy beef cattle either sired naturally by unrecorded Hereford bulls or sired by Hereford bulls with high EBV's for calving ease and growth, via either $\mathrm{AB}$ or natural mating.

\section{Methods}

The experiment was conducted, with the approval from the Ruakura Animal Ethics Committee, on AgResearch farms in the Waikato; the Tokanui dairy farm and the Whatwhata hill country sheep and beef farm.

Dams were mixed age and of at least half Holstein Friesian parentage, with the balance being Jersey. A subset of 235 low breeding worth cows from the Tokanui dairy herd were selected for $\mathrm{AB}$ using Hereford beef sires if identified on heat between 7 October and 20 November 2011. Sires were allocated across dams, balanced for dam age, liveweight, breed and breeding worth. Following AB, a mixture of 3 Ezicalve Hereford bulls and 22 unrecorded Hereford bulls were rotated with the entire dairy herd for 4 weeks.

The semen used was from 3 Ezicalve Hereford sires; Ardo Caspian 6159, Koanui Rocket 0219 and Ardo Russia 4133. They had calving ease EBV's in the top $1 \%$ for their breed, birth weight EBV's of -1.2, -0.8 and $-1.8 \mathrm{~kg}$, respectively, and 600 day weight EBV's of $+43,+69$ and $+45 \mathrm{~kg}$, respectively. For natural mating, the Ezicalve bulls had birthweight EBV's of -0.5 to -0.8 $\mathrm{kg}$ and 600 day weight EBV's of +46 to $+64 \mathrm{~kg}$.

Calving began on 9 July 2012, with AB sired calves 
born in the first 8 weeks and naturally sired calves born from weeks 7 to 11 . There were 106 Ezicalve AB sired calves, 23 Ezicalve naturally sired calves and 57 calves sired naturally by unrecorded bulls. Those assisted at calving were recorded and new-born calves were collected 6 hourly and individually fed two litres of colostrum. Calves were then weighed and an ear punch sample was taken for DNA parentage verification by Livestock Improvement Corporation (LIC).

Calves were grouped with up to 10/pen of similar size and feeding ability, with continual access to fresh water and $20 \%$ protein meal. Following 4 days of feeding colostrum, SupaCalf $^{\mathrm{TM}}$ calf milk replacer mixed with whole milk was fed at 4 litres/calf/day for the first week, five litres/calf/day for the following 2 weeks, then was gradually reduced to two litres/calf/ day up to week 8 , with the calves remaining on this allowance until weaning. Male calves were castrated at 6 to 8 weeks of age. All calves were weighed fortnightly and were transferred to pasture between 3 and 9 weeks of age, dependent on their liveweight, weather conditions and space in the calf shed. Individual calves were weaned off milk at $85 \mathrm{~kg}$ liveweight and off meal at $100 \mathrm{~kg}$ liveweight, at which point they were transferred to the Whatawhata farm for finishing.

Calves were transferred to Whatawhata between 11 November 2012 and 10 January 2013 and rotationally grazed pasture under the farm's standard management practices on rolling to steep land. Animal health was managed under veterinary advice and included annual vaccinations for clostridial disease and leptospirosis, $\mathrm{B}_{12}$, selenium and copper administration in their first year and preventative treatment for lice and internal parasites. All of the calves were initially managed as one mob, before separation into steer (90) and heifer (96) mobs in February 2014. The cattle were weighed every 1 to 3 months until September 2014, when the first of the heifers reached the slaughter target of 500 $\mathrm{kg}$ liveweight. Pre-grazing pasture samples were collected every 1 to 3 months to the estimated grazing height for assessment of nutritive value by near infrared reflectance spectroscopy (Corson et al. 1999).

Data were analysed with Genstat (version 17), except those from twin calves. Data were adjusted for gender and dam liveweight (weekly average to 3 December 2011) before analyses. For the sire type effect on liveweight, data were analysed with and without date of birth as a covariate, to account for the earlier birth dates of $\mathrm{AB}$ sired cattle.

\section{Results}

$\mathrm{AB}$ and naturally sired Ezicalve progeny had similar birth weights, but averaged $4 \mathrm{~kg}$ lighter than the progeny of unrecorded sires (Table 1). The average growth rate of calves during rearing was similar across sire types (Table 1), reaching $100 \mathrm{~kg}$ at an average of 13 weeks of age $(\mathrm{P}>0.1)$. Because they were born an average of 5 weeks earlier, the AB Ezicalve calves reached $100 \mathrm{~kg}$ liveweight about 5 weeks earlier (6 November) than those sired naturally by either Ezicalve or unrecorded sires $(\mathrm{P}<0.001)$. Ezicalve sired calves had no calving assistance, while two (4\%) of the calves sired by unrecorded bulls were assisted at birth. However, the low incidence of calving assistance prevented statistical analysis of these data.

The pastures grazed on the finishing farm ranged in metabolisable energy (ME) from 8.8 to $12.1 \mathrm{MJ} /$ $\mathrm{kg} \mathrm{DM}$ and in crude protein concentration from 11 to $29 \%$ of DM. ME was below $10.0 \mathrm{MJ} / \mathrm{kg}$ DM between December 2012 and April 2013 and between January and May 2014, when droughts occurred.

On the finishing farm, the Ezicalve AB cattle averaged 20 to $35 \mathrm{~kg}$ heavier than those calves sired by natural mating at any given date $(\mathrm{P}<0.001$; Figure 1$)$, whilst the cattle sired naturally by Ezicalve and unrecorded bulls had similar liveweights (Figure 1). However, when liveweight data were adjusted for date of birth, there were no differences between sire types in liveweight gain (Table 1) or liveweight during finishing.

Sires within the Ezicalve AB group produced calves of similar birth weights $(\mathrm{P}>0.1)$ and growth rates during rearing $(\mathrm{P}>0.1)$, but growth rates during finishing (from

Table $1 \quad$ Adjusted mean birth weight and liveweight gain (LWG) of dairy beef cattle sired by artificial insemination with Ezicalve Hereford semen (Ezicalve $\mathrm{AB}$ ) or naturally sired by Ezicalve (Ezicalve natural) or unrecorded Hereford sires (unrecorded natural). Data were adjusted for gender (heifer and steer) and dam liveweight. Means within columns with the same letter are not significantly different at the $5 \%$ level.

\begin{tabular}{lcccc}
\hline & $\begin{array}{c}\text { Birth weight } \\
(\mathbf{k g})\end{array}$ & $\begin{array}{c}\text { LWG from birth } \\
\text { to 100 kg } \\
(\mathbf{k g} / \mathbf{c a l f} / \text { day })\end{array}$ & $\begin{array}{c}\text { LWG from birth } \\
\text { to 2 years } \\
(\mathbf{k g} / \text { calf/day) }\end{array}$ & $\begin{array}{c}\text { LWG from 100 kg } \\
\text { to 2 years } \\
(\mathbf{k g} / \mathbf{c a l f} / \mathrm{day})\end{array}$ \\
\hline Ezicalve AB & $38.1^{\mathrm{a}}$ & $0.68^{\mathrm{a}}$ & $0.53^{\mathrm{a}}$ & $0.51^{\mathrm{a}}$ \\
Ezicalve natural & $38.4^{\mathrm{a}}$ & $0.69^{\mathrm{a}}$ & $0.54^{\mathrm{a}}$ & $0.52^{\mathrm{a}}$ \\
Unrecorded natural & $41.9^{\mathrm{b}}$ & $0.67^{\mathrm{a}}$ & $0.54^{\mathrm{a}}$ & $0.52^{\mathrm{a}}$ \\
SED & 1.51 & 0.02 & 0.012 & 0.013 \\
\hline
\end{tabular}




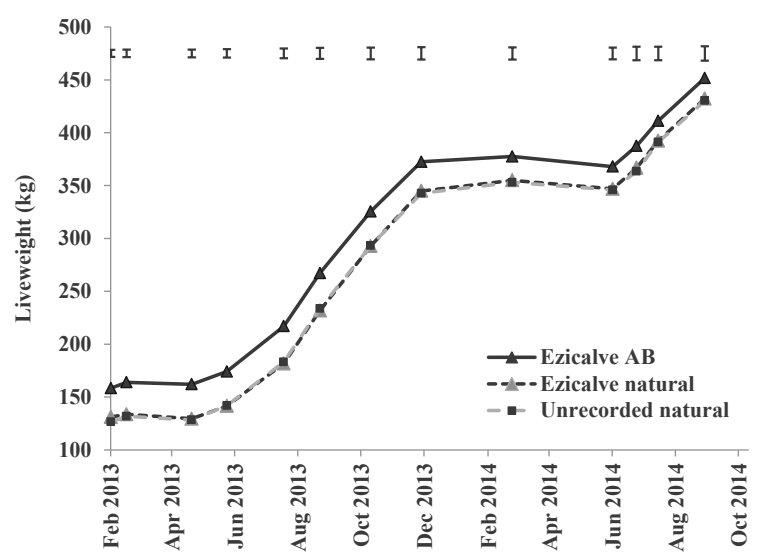

Figure 1 Mean liveweight of dairy beef cattle from approximately 5 months (with $A B$ cattle older) to 2 years old from Ezicalve $A B$, Ezicalve natural and unrecorded natural Hereford sires. Error bars represent LSD $(\mathrm{P}<0.05)$. Means were adjusted for gender (steer and heifer) and dam liveweight.

$100 \mathrm{~kg}$ to approximately 2 years of age) were slightly greater for progeny of Koanui Rocket $(0.54 \mathrm{~kg} /$ day $)$ than those sired by Ardo Russia ( $0.50 \mathrm{~kg} / \mathrm{day})$ or Ardo Caspian $(0.50 \mathrm{~kg} /$ day $)(\mathrm{P}<0.01)$.

\section{Discussion}

The use of recorded beef sires with high EBV's for calving ease and 600 day weight in a dairy herd resulted in lower birth weights, which is of benefit to calving ease, but did not compromise the rearing or finishing performance of the progeny. Use of beef sires during $\mathrm{AB}$ can also bring forward the date of supply of weaner calves to the beef industry, with a greater potential to finish cattle before their second winter.

The lack of calving assistance for Ezicalve sired calves is of value to dairy farmers, but the overall low incidence of calving problems in this project makes the quantification of sire effect difficult. Laster (1974) reported calving difficulty frequency increased by $2.3 \%$ for each $\mathrm{kg}$ increase in calf birth weight with Angus and Hereford dams. Applying this equation to our study with predominantly Friesian dams, it would equate to an 8-9\% decrease in calving problems when comparing the Ezicalve to the unrecorded Hereford sires. Hickson et al. (2015) also concluded that beef bulls with appropriate birth weight EBV's should produce calves of similar birth weight to those sired by dairy bulls, indicating no increased risk of calving problems when used on dairy farms.

The average growth rate across sire types during rearing was within the range of 0.63 to $0.77 \mathrm{~kg} / \mathrm{day}$ reported by Muir et al. (2000) for calves reared under different commercial nutritional regimes. Despite lower birth weights, $\mathrm{AB}$ and naturally sired Ezicalve progeny took a similar length of time to reach 100 $\mathrm{kg}$ liveweight as calves sired by unrecorded bulls, indicating that the use of sires with low birth weight EBV's may not negatively impact calf rearing. However, as calves were not separated by sire type for feeding, it is unknown if they consumed more feed to reach this target.

The feed quality of the pastures offered to cattle during summer and autumn were often below that required for achieving high liveweight gain (Smeaton 2003), limiting the ability of the cattle to express their full genetic potential for growth. This low summerautumn feed quality is typical of New Zealand hill country (Rennie et al. 2014) and the growth rates of the cattle from $100 \mathrm{~kg}$ to approximately 2 years of age in this study was similar to the average of a group of New Zealand farms reported by Everitt et al. (1980) for Hereford-Friesian cross steers $(0.52 \mathrm{~kg} /$ day from 100 $\mathrm{kg}$ to slaughter).

Although the growth rates of the progeny during finishing was similar amongst sire types, the slightly higher rate of liveweight gain for cattle sired by Koanui Rocket 0219 compared to those sired by the other Ezicalve $\mathrm{AB}$ sires shows the potential of cattle with high EBV's for 600 day weight to grow faster on hill country than those with lower EBV's. Everitt et al. (1980) also showed differences amongst sires within breeds for growth rates of dairy beef cattle over a similar age, highlighting the value of knowing the genetic merit of individual bulls.

Economic analyses and further monitoring of a second cohort of cattle born in 2013 from the same AB sires and different natural breeding sires, will provide a more comprehensive evaluation of the effects of using unrecorded or high genetic merit bulls on the lifetime performance of dairy beef cattle.

\section{ACKNOWLEDGEMENTS}

Funds were provided by the Mid-Northern North Island Beef + Lamb New Zealand Farmer Council, with inkind support by LIC and Ezicalve. We thank Catherine Cameron and AgResearch farm staff at Tokanui and Whatawhata and members of the Mid-Northern North Island Beef + Lamb New Zealand Farmer Council for input into the project.

\section{REFERENCES}

Beef + Lamb New Zealand Economic Service. 2014. Stock Number Survey as at 30 June 2014. http://www. beeflambnz.com/Documents/Information/Stock $\% 20$ number\%20survey.pdf Accessed: 2/9/2015.

Corson, D.C.; Waghorn, G.C.; Ulyatt, M.J.; Lee, J. 1999. NIRS: Forage analysis and livestock feeding. Proceedings of the New Zealand Grassland Association 61: 127-132. 
Everitt, G.C.; Jury, K.E.; Dalton, D.C.; Langridge, M. 1980. Beef production from the dairy herd. IV. Growth and carcass composition of straight-bred and beef cross Friesian steers in several environments. New Zealand Journal of Agricultural Research 23: 11-20.

Hickson, R.E.; Zhang, I.L.; McNaughton, L.R. 2015. Brief communication: Birth weight of calves born to dairy cows in New Zealand. Proceedings of the New Zealand Society of Animal Production 75: 257-259.

Laster, D.B. 1974. Factors affecting pelvic size and dystocia in beef cattle. Journal of Animal Science 38: 496-503.
Muir, P.D.; Nieuwenhuis, G.; Smith, N.B.; Ormond, A.W.A. 2000. A comparison of rearing systems for dairy beef calves. Proceedings of the New Zealand Grassland Association 62: 9-11.

Rennie, G.M.; King, W.McG.; Knight, T.L.; Devantier, B.; Hoogendoorn, C.J. 2014. Improving summer and autumn feed quality in New Zealand Hill Country. Proceedings of the New Zealand Grassland Association 76: 145-148.

Smeaton, D.C. 2003. Requirements of artificially reared beef calves to age 6 months. pp. 38-50. In: Profitable beef production. A guide to beef production in New Zealand. Ed. Smeaton, D.C. New Zealand Beef Council. 